\title{
Influence of the Guided Discovery Learning Model on Primary School Students' Mathematical Problem-solving Skills
}

\author{
Akhmad Badrul Lubis $^{\bowtie 1}$, Yalvema Miaz², \& Indah Eka Putri \\ 1,2 Primary Education, Universitas Negeri Padang, Padang, Indonesia \\ 3 Primary School Teacher Education, Universitas Bung Hatta, Padang, Indonesia \\ $\bowtie$ akhmadbadrul@gmail.com
}

\begin{abstract}
Difficulties of primary school students in solving mathematical problems that require problem solving or reasoning abilities indicate the existence of problems in the process of learning mathematics, because one of the purposes of learning mathematics in primary school is to develop the students' mathematical problem-solving skills. As a solution to overcome the problems, this research aims at understanding how the implementation of the guided discovery learning model influences mathematical problem-solving skills. This research employs a quasi-experimental design by involving all fifth-grade students at one of primary schools in Tebo Regency, Jambi. The simple random sample was conducted to obtain class VB as experimental class, and class VA as control class. Based on the results of the final score, experiential class obtained an average score of 86.00, and control class obtained an average score of 76.93. The results of hypothesis test using t-test obtained $t_{\text {count }}=2,203>t_{\text {table }}=2,020$, which indicated that $\mathrm{H}_{0}$ was rejected, and $\mathrm{H}_{1}$ was accepted. Therefore, the guided discovery learning model influenced the fifth-grade students' mathematical problem-solving skills, thus it is recommended for teachers to be able to use the guided discovery learning model in the mathematics learning process.
\end{abstract}

Keywords: 2013 curriculum, guided discovery learning model, mathematical problem-solving skills, primary school

How to Cite: Lubis, Akhmad Badrul, et al. (2019). Influence of the Guided Discovery Learning Model on Primary School Students' Mathematical Problem-Solving Skills. Mimbar Sekolah Dasar, 6(2), 253-266. doi:10.17509/mimbar-sd.v6i2.17984.

INTRODUCTION Primary school is the most important part of learning that every student must pass successfully. The success at primary school level will determine success at a further stage. At this level, classroom teachers have the responsibility to teach five fields of study. Mathematics is one of five subject areas, which is taught by teachers as an effort to improve and maintain the quality of human resources (Şahin, 2018). Through the implementation of mathematics learning, every generation in Indonesia is expected to develop the ability of students to think logically in determining how to solve a problem, to train students' analytical thinking in solving a problem accurately and appropriately, and to train students in sorting a problem solving systematically, so that the students have the ability to solve problems experienced directly in daily life (Elfiadi, 2015).

The occurrence of a fundamental change in people's lives in the 21st century (Wijaya, Sudjimat, \& Nyoto, 2016) has affected primary school participation in major changes (Anderson-levitt, Sirota, \& 
Mazurier, 2016). This causes the needs of learning that is able to produce educational needs to produce students with problem-solving skills in mathematics, has become something important to be considered. Changes that occur rapidly in the present will provide opportunities, if it is properly utilized, but it can be disastrous, if it is not systematically planned, structured, and measurable (Redhana, 2019). Basically, the mission of the educational system is to produce students who have the ability and skills in accordance with the needs of every generation (Gürbüztürk, 2018), because in fact, mathematics is considered as a science education that always seeks to overcome problems of each generation (Condon \& Wichowsky, 2018).

Indonesia, as a large developing country, must consider the current development, especially those related to basic education (Prearse, 2014), as predicted that in the year 2045, Indonesia will obtain demographic bonus (Kemenku, 2017), in which the number of working or productive age population (Indonesian golden generation) is greater than the old or unproductive population. If this generation is well prepared by the Indonesian educational institutions, they will be able to positively accelerate the progress of Indonesia in every aspect of life, especially in the aspects of technology, education, arts and culture (Prayitno, 2015).

Pasaribu (2017) defines mathematics as a determinant part of the development and students' self-realization of in primary school education. It is expected to realize the golden generation of Indonesia with the ability to implement their knowledge in every development situation (problemsolving) that develops rapidly (Prastiwi, 2018), thus, the students are used to solving problems that occur in complicated daily life (Nurhanifah, 2018), and being as provisions to answer future needs by being actively involved in determining change in the world.

The problem-solving ability is a logical thinking process in determining the most appropriate way to solve a problem. According to Polyo (in Rahayu \& Afriansyah, 2015), problem solving is defined as an intellectual activity in solving a problem encountered based on the provision of knowledge, so that every student needs to have it as evidence of their participation in learning mathematics taught by teachers in primary school.

According to Charles and O'Daffer (in Harahap \& Surya, 2017), the purpose of teaching mathematical problem-solving skills of students is to boost their thinking skills, to enhance the ability to choose and determine the right strategy in solving a problem, to develop attitudes and confidence in solving problems, to get used to using their knowledge in connecting theory with practice, to train them to monitor and assess their own thoughts and work in solving problems, to get used to solving problems in a cooperative condition, to get used to finding the correct 
Akhmad Badrul Lubis, Yelvema Miaz, \& Indah Eka Putri, Influence of the Guided Discovery Learning...

answer from a variety of different problems. Based on these objectives, it is expected that the learning process of mathematics in primary schools' students regarding problem-solving, will produce students who are able to answer the challenges of dynamic world change.

However, in fact, the main problem in the implementation of mathematics learning at the primary school level in Indonesia is that mathematical problem-solving skills of primary school students in Indonesia are low. This was evidenced from the research findings of Trends in International Mathematics and Science Study conducted by Frederick K. S (in Elfiadi, 2015), which shows that students in Indonesia had a low problem-solving ability compared to the problem-solving skills of students from various countries, including most countries in the Asian region.

This is due to the implementation of learning in Indonesia that is only referring to procedural matters, thus the learning has not emphasized the problem-solving, which is carried out by the students themselves. Regrettably, the learning only emphasizes on the students' ability to memorize formulas, but with limited implementation, so that the students face difficulty in answering complex questions requiring a logical explanation. The data are also supported by Indonesia's ranking in the research about the mastery of mathematics by Indonesian children conducted by Programme for International Student Assessment (PISA) Survey in 2015, by involving 15-year-old learners, in Indonesia was ranked at 63rd out of 70 countries in the world (Antara, 2017). Lack of the ability of the Indonesian students in solving mathematics problems has a negative effect on the quality of human resources, because the schools cannot optimally maximize all abilities of each Indonesian student as the next generation (Cahyani \& Setyawati, 2016).

In general, the most primary school students regard mathematical problemsolving as a very challenging skill to master (Özsoy, 2018). The government has conducted various ways to improve the quality of Indonesian education, so that students have the ability to solve mathematical problems. One of the most and fundamental changes conducted by the Indonesia government is curriculum changes, for examples, the shift of KTSP curriculum into to 2013 Curriculum with the novelty in almost every component, particularly in the implementation of integrated thematic learning in each subject by using a scientific approach (Utami, Yamtinah, \& Es, 2016). In attempting to support this change, the training was held for teachers to implement the learning using 2013 Curriculum, even though there were several obstacles in its implementation in the classroom (Artapati \& Budiningsih, 2017)

The most important aspect to be recognized is that the learning conducted in the classroom by teachers determines the quality of students' mathematical 
problem-solving skills (Wasserberg, 2018). Mathematics, as a subject related to counting activities, indeed determines how good the quality of students' problemsolving skills, because it is related to the arithmetical skills (Ulu \& Özdemir, 2018). Therefore, Griffen (2015) states that learning in classroom will determine the quality of students produced. Homeroom teachers as an educator who are responsible in classroom become the main factor in determining the students' problem-solving skills. According to Shabir (2015), since homeroom teachers directly face the students in classroom, they must be able to implement the learning in classroom that is interesting for students, so that they can like mathematics, especially related to arithmetic in developing the students' problem-solving skills.

In fact, the teachers at primary school level are expected to create successful development of problem-solving skills based on a result of learning activities on five subjects (Mccloskey \& Quay, 2018), which is still cannot be obtained in the process of mathematics learning. Meanwhile, mathematics learning should prioritize the learning process and create classroom situation that provides opportunities for the students to find their own knowledge to be applied in solving their problems. Hence, they will get used to carry out certain problem-solving activities related to mathematics, and even other four subjects. However, this learning is even implemented with the conventional learning process that emphasizes paradigm in learning outcomes as a determinant of the successful implementation of learning mathematics and other subjects. Thus, the learning is only conducted implementing a scientific approach without any consideration. Therefore, the results are still not able to develop the maximum mathematical problem-solving skills of students.

Based on the aforementioned general problems, it was found that in fifth-grade at one of primary schools in Tebo Regency, Jambi, the learning was still found implementing the one-way learning, i.e. teachers are more active in delivering learning material to students (Astra \& Sumiati, 2008), thus it resulted in some students could not focus on the learning, and they only passively listened to teachers, got sleepy, and played objects that are not related to its learning. In this learning process, the students were assigned to memorize some of the formulas learned in each meeting, without applying it correctly to complex questions.

In addition, the students have not been taught to find their own concepts or formulas to be mastered. In the learning activities conducted by the teachers, the students passively obtained learning material presented by the teachers. These problems are also found in other research in which the results revealed that the students still had low mathematical problem-solving skills, so that it raised the idea in the students' mind that 
Akhmad Badrul Lubis, Yelvema Miaz, \& Indah Eka Putri, Influence of the Guided Discovery Learning...

mathematics is a difficult or boring subject to learn (Rahayu \& Afriansyah, 2015). This understanding resulted in the lack of the implementation of learning conducted by the teachers, and some students had a low attendance when learning mathematics, which is very influential on students' understanding of the material and subsequent problem-solving skills (Kirksey \& Gottfried, 2018).

The problem identification in this research is that the students had low problem-solving skills, due to conventional mathematics teaching performed by the teachers. Hence, the students considered that mathematics was a difficult and boring subject to learn because it was related to calculations that are difficult to understand. However, it should be realized that the learning process also has an impact on students' inactivity in classroom, because the learning activity is considered boring by students since they were only asked to memorize formulas without having opportunities to apply it. Thus, they were not used to find their own formula to solve the problems in mathematics.

If this kind of learning still remains, it can negatively affect the students' abilities to compete with other students in regions, national and international scopes. Thus, it is believed to be difficult to determine their development in Indonesia.. Hence, it requires the appropriate response to improve the learning process.
The previous research showed that the appropriate implementation of guided discovery learning model in mathematics was able to improve and train the students' mathematical problem-solving skills (Kara \& Incikabi, 2018). Moreover, the determination of a specific model in a learning can improve students' academic performance (Käsper, Uibu, \& Mikk, 2018). Oneof the proposed models is developing problem-solving skills, which can be implemented to overcome problems in the implementation of mathematics. Based on the literature review and research that had been conducted previously, the problems occurred in the process of learning mathematics can be overcome by implementing the guided discovery learning model. This learning model's emphasis is on giving questions from teachers (in the form of problems) rather than giving explanations to students, and this is also considered as a model that provides opportunity for the students to compile, process and arrange data assigned correctly (Nerita, Hartati, Maizeli, \& Afza, 2019), This is in line with Freudental (in Rusmiati, 2014), stating that Mathematics is not a product presented in a finished form, instead students must learn and find it independently with teachers as facilitators, so that the students are more active in solving problems provided by teachers. Previous researchers who have conducted research on the guided discovery learning model include: 
Lendi (2015) conducted the research on the effect of the guided discovery learning strategy to the fifth-grade primary school students' critical thinking ability in the process of learning natural sciences. Theresearch results revealed that there was a significant influence between the model used by the researcher and the students' critical thinking ability in the process of learning natural sciences. Additionally,Aini, Tukiran, \& Qosyim (2013) conducted the research on the guided discovery integrated learning the Webbed type on the theme of Biopesticides. The research results revealed that this model had a significant effect on three learning aspects (behaviors, knowledge, and skills) of the students.

The novelty of abovementioned previous research is on the implementation of Guided Discovery, which was done using scientific approach by conducting several activities, such as: observing, asking, gaining information, experimenting, and communicating, which was the characteristic of 2013 Curriculum. Even though the scientific approach was not done sequentially, since it was made to be appropriate with the learning model. However, this Guided Discovery learning was implementedit sought to see how it affected the students' problem solving skills on mathematical problems provided by teachers.

According to aforementioned issues, this research seeks to provide solutions to those issues by conducting research entitled
Influence of Guided Discovery Learning Model on Primary School Students' Mathematical Problem-Solving Skills.

\section{METHOD}

This research employs a quasi-experimental design, which was implemented to examine the influence of the guided discovery learning model to the fifth-grade students' mathematical problem-solving skills in Tebo Regency, Jambi. According to Suryabrata (2006), the experimental research aims at obtaining causality from the experimental group applied to several treatment conditions that are then compared with the results of the control group, which were not given the same treatment as the experimental group. Thus, the researchers are able to know how the guided discovery learning model influenced the students' problem-solving skills. Through statistical calculations, it is expected to answer the predetermined hypothesis.

The population of this research was all fifthgrade students at one of primary schools in Tebo Regency, Jambi. There were 43 fifthgrade students selected who were 11-12 years old. Piaget (in Ufie, 2017) states students at this age have a concrete operational stage in the development of knowledge, so that it has its own differences in solving problems, especially those relating to concepts that exist in mathematics learning, in which the students unconsciously have it. Based on the data of daily tests done using validity, 
Akhmad Badrul Lubis, Yelvema Miaz, \& Indah Eka Putri, Influence of the Guided Discovery Learning...

homogeneity test, and Mann-Whitney $U$ tests, the results revealed that the data of daily test showed that the class data were normally distributed, homogeneous variance, and had average similarity, thus by using Simple Random Sampling (SRS), class 5B was determined to be a class with the implementation the guided discovery learning model (experimental class), and class $5 \mathrm{~A}$ was determined to be a class with the implementation of conventional learning (control class).

The research was conducted in three stages: planning activity stage (determining the location and schedule of the research to testing the questions), the implementing activity stage (conducting learning activities in experimental class using the guided discovery learning model, and in the control class using conventional learning), and completing activity stage (conducting the final test to the sample classes to making a research). The instrument used to determine the students' mathematical problem-solving skills is a list of questions that required problem-solving skills, which were administered to the students to solve by both of the classes. The results were checked using 4-point scale rubric, namely analytical rubric, so that teachers could make assessments based on certain criteria, so they were able to analyze the strengths and weaknesses of each student based on predetermined criteria.

This research was conducted from 20 April 2018 to 5 May 2018 at one of the primary schools in Tebo Regency, Jambi, in which the $5 \mathrm{~B}$ class was determined as an experimental class and the $5 \mathrm{~A}$ class was determined as a control class. In each class, there were five meetings conducted with the implementation of $\mathrm{KI}-3$ and $\mathrm{KI}-4$ (Kemendikbud, 2016), which is as follows:

Table 1. The Core Competence and Basic Competence.

\begin{tabular}{|c|c|}
\hline KI (Kompetensi Inti - Core Competence) & $\begin{array}{l}\text { KD (Kompetensi Dasar - Basic } \\
\text { Competence) }\end{array}$ \\
\hline $\begin{array}{l}\text { 3. Understand factual and conceptual knowledge by } \\
\text { observing and questioning based on curiosity about } \\
\text { himself, God's creatures and their activities, and objects } \\
\text { found at home, at school, and at playgrounds. }\end{array}$ & $\begin{array}{l}\text { 3.6 Explain and determine } \\
\text { simple building blocks (cubes } \\
\text { and blocks). }\end{array}$ \\
\hline $\begin{array}{l}\text { 4. Provide factual and conceptual knowledge in clear, } \\
\text { systematic, logical and critical language, in aesthetic } \\
\text { works, in movements reflecting healthy children, and in } \\
\text { actions reflecting the behavior of children who have a } \\
\text { faith and noble character. }\end{array}$ & $\begin{array}{l}\text { 4.6 Making simple building } \\
\text { blocks (cubes and blocks). }\end{array}$ \\
\hline
\end{tabular}

In order to find out the findings of this research, several tests were conducted. if the data were normally distributed and homogeneous variance, the t-test was used, if the data were normally distributed, but not homogeneous variance, the t-test and the Mann-Whitney test was used if the research data were not normally distributed. 
After conducting the learning process, and providing the final test to the sample classes, the obtained results are as follows.

Table 2. Result of Students' Final Tests.

\begin{tabular}{llllll}
\hline Class & $\begin{array}{l}\text { Number of } \\
\text { Students }\end{array}$ & $\begin{array}{l}\text { Maximum } \\
\text { Score }\end{array}$ & $\begin{array}{l}\text { Minimum } \\
\text { Score }\end{array}$ & $\begin{array}{l}\text { Students who achieve } \\
\text { Minimum Criteria of } \\
\text { Mastery Learning (KKM, } \\
\text { Kriteria Ketuntasan } \\
\text { Minimum) }\end{array}$ \\
\hline Experimental & 21 & 100 & 75 & 18 & $85.71 \%$ \\
Control & 22 & 90 & 53 & 15 & $68.18 \%$ \\
\hline
\end{tabular}

Source: The data of the students' final tests

Table 2 presents that the KKM was 75 . Moreover, the experimental class with 21 students obtained the maximum score of 100 , and the minimum score of 75 , and the number of students who had a score above KKM was 18 students (85.71\%), which was higher than the control class with 22 students that obtained the maximum score of 90 , and the minimum score of 53 , and the number of students who had a score above KKM was 15 students (68.18\%).

Data Analysis
After obtaining the final test calculation results, several tests were conducted, namely normality tests, data homogeneity tests, and statistical tests conducted to answer the research hypotheses, with the explanation as follows:

\section{Normality Test}

In this research, the Lilliefors test was used for data normality testing. Based on the Lilliefors test on the experimental and control classes, the results obtained that Lo and Ltable with a real level $=0.05$, which is presented in Table 2:

Table 3. Result of Normality Test on the Sample Class.

\begin{tabular}{lllll}
\hline Class & $\mathbf{N}$ & $\mathbf{L}_{0}$ & $\mathbf{L}_{\text {table }}$ & Information \\
\hline Experimental & 21 & 0.1038 & 0.186 & Normal \\
Control & 22 & 0.1832 & 0.183 & Normal \\
\hline
\end{tabular}

Source: The data of the students' final tests

Table 3 presents that the experimental class obtained Lo of $0.1038<$ Ltable of 0.186 , while the control class obtained Lo of $0.1832<$ Ltable of 0.183 , so that it can be concluded that the results of normality test revealed that the both sample class data had normally distributed.

\section{Homogeneity Test}

The data homogeneity test was conducted to determine whether two sample classes had homogenous in variance or not. The homogeneity test was conducted using Ftest. The results of determining homogeneity from the research data obtained that the calculation results are as follows: 
Akhmad Badrul Lubis, Yelvema Miaz, \& Indah Eka Putri, Influence of the Guided Discovery Learning...

Table 4. Result of Homogeneity Test on the Sample Class.

\begin{tabular}{lcll}
\hline Class & Fcount & Ftable & Information \\
\hline Experimental \& Control & 1.99 & 2.11 & Homogeneous Variance \\
\hline Source: The data of the students' final tests & \\
Table 4 presents that the both sample & After conducting the normality and \\
classes had Fcount of $1.99<$ Ftable of 2.11. The & $\begin{array}{l}\text { homogeneity tests, the results revealed that } \\
\text { the data were normally distributed and } \\
\text { classes had homogenous variance data. }\end{array}$ & $\begin{array}{l}\text { homogeneous variance, thus, the } \\
\text { hypothesis testing was conducted using t- } \\
\text { test with the calculation results as follows: }\end{array}$
\end{tabular}

Table 5. Result of Hypothesis Test on the Sample Class.

\begin{tabular}{lllll}
\hline Class & S & tcount & trable & Conclusion \\
\hline Experimental \& Control & 14.21 & 2.203 & 2.020 & HI was accepted \\
\hline Source: The data of the students' final tests & & &
\end{tabular}

Source: The data of the students' final tests

Table 5 presents that the both sample classes had tcount of 2.203 and table of 2.020, or $t_{\text {count }}>t_{\text {table, }}$ which indicated that $\mathrm{H}_{1}$ was accepted, or the guided discovery learning model had an influence on the students' mathematical problem-solving skills.

\section{DISCUSSION}

The research results revealed that the guided discovery learning model with a scientific approach was able to achieve KI in mathematics subjects, because the model is considered suitable for learning in primary school. The characteristics of mathematics subjects in primary education units, starts from knowing the concepts, finding formulas, doing problem solving, to reasoning, so that this learning model can change the learning process in a good direction, it is expected to be able to create future generations that will be distinctive from current generations (Uusiautti, Paksuniemi, \& Matta, 2013).

In addition, the consideration of the implementation of the guided discovery model in KD 3.6, which explains and determines simple building blocks (cubes and beams), was compatible with the implementation of learning conducted concretely related to introduction of simple concepts in learning, thus the researchers were able to see the influence of the learning model on the students' mathematical problem-solving skills. The results revealed that the models could achieve the $\mathrm{KI}$ andthe implementation of guided discovery education models 
implemented in schools aims at changing the conventional learning conducted by teachers, since Kostelecká (2010) affirms that conventional learning is strongly influenced by country's political and cultural systems. This is considered significant, since the achievements in mathematics have become one of the world's concerns in the education field (Ozerk, 2018).

The successful implementation of the guided discovery learning model has developed the fifth-grade primary school students' mathematical problem-solving skills (Abalı \& Kaan, 2018). According to Nahdi (2018), the research results revealed that the guided discovery learning model had a good influence on the students' problem-solving skills. Similarly, Nupita's (2013) research revealed that the guided discovery learning model had a positive influence on the fifth-grade primary school students' problem-solving skills in natural sciences. These research results are in line with the results of this research, which revealed that the guided discovery learning model had an influence on the fifth-grade primary school students' mathematical problem-solving skills. Thus, this research strengthened the previous research results, especially in introducing the implementation of the guided discovery learning method in 2013 Curriculum by using the scientific approach in developing the fifth-grade primary school students' mathematical problemsolving skills, which is in the final stages of development of knowledge from concrete operations to formal operations. This learning had been conducted to change the students' knowledge (Winne, 1985).

Through various series of activities, the results of the final test of the experimental class that was exposed toguided discovery learning model, was better than the control classes that was exposed toconventional learning.This was evidenced by the final test scores of the experimental class students obtaining an average score of 86.00, while the control class obtaining an average score of 76.93 . This research can be used to differentiate the quality of learning (Park, 2017), because what is received (information) by the students at each meeting will be able to have a significant influence on the development of the students' problem-solving skills (Temur, 2012).

If the experimental class and the control class are compared with the two data, the obtained conclusion would-be that the experimental class with the guided discovery learning method resulted in the better mathematical problem-solving skills, compared to the control class with the conventional learning.

In addition to the comparison of the average scores of students, after conducting a series of tests, such as normality, homogeneity, and hypotheses tests, the results showed that the data were normally distributed, and homogeneous variance, which fulfilled the prerequisites to 
Akhmad Badrul Lubis, Yelvema Miaz, \& Indah Eka Putri, Influence of the Guided Discovery Learning...

answer the hypothesis by using t-test. The results revealed that $t_{\text {count }}$ of $2.203>t_{\text {table }}$ of 2.020, which indicated that the guided discovery learning model, had an influence on the fifth-grade students' mathematical problem-solving skills at one of primary schools in Tebo Regency, Jambi.

Based on the final test conducted by the researcher, the test given has an important role in the learning process (Sahin, 2018), In attempting to understand the students' problem-solving skills in the experimental and control classes, the percentage of indicators for each item was analyzed to see the students' mathematical problemsolving skills in each question that contains indicators. After conducting the calculation in the experimental class, the results revealed that the highest percentage of questions were in question $2 a$ on the scale of 3 with the indicators of $A$ and $C$, and the average items of $100 \%$, while the lowest percentage of questions were in question 7 on the scale of 3 with the indicators of $A$ and $B$, and the average items of $44.44 \%$. Meanwhile, in the control class, the highest percentage of questions were in question $2 b$ on the scale of 3 with the indicators of $A$ and $B$, and the average items of $75.45 \%$, while the lowest percentage of questions were in question 7 on the scale of 3 with the indicators of $A, B$, and $C$, and the average items of $47.47 \%$. The results indicated that the learning model could affect the students' problemsolving skills well, because the future education must be able to produce the students who can answer world changes occurred quickly, with the students' problem-solving skills (Kim \& Lee, 2018).

Based on the aforementioned explanation, in the process of problem-solving activities, the students in the experimental class had a better ability to solve problems provided by the teacher. In contrary, the students in the control class tended to have difficulty in solving problems, since many of the students answered the questions incorrectly , so that the results revealed that the guided discovery learning model had an influence on the fifth-grade primary school students' mathematical problem-solving skills, and the interrelation of each subject in supporting the development of mathematical problem-solving skills is required by students to provide a greater opportunity to learn (Barney \& Deutsch, 2012) Therefore, mathematics is a field of study consisting of concepts, abstracts, algorithms, and symbols, which are directly related to the real world of students (Kara \& Incikabi, 2018).

\section{CONCLUSION}

The conclusion of the implementation of this research showed that the average score of the students' final test obtained in the experimental class was 86.00 while in the control class, the students had an average value of 76.93 . Then the students' final test data was analyzed using a statistical test to answer the hypothesis then $t_{\text {count }}>t_{\text {table }}$ or $2.203>2.020$, in meaning that $\mathrm{H}_{0}$ was rejected and $\mathrm{H}_{1}$ was accepted. 
Thus, the drawn conclusion is that the implementation of the guided discovery learning model had an influence on the students' mathematical problem-solving skills.

This research results are expected to be useful for every party who plays a direct role in the primary school education, especially for teachers who teach mathematics to fifth-grade at primary school who seekto implement the guided discovery learning model with a scientific approach to produce learning that develops the students' mathematical problem-solving skills.

\section{REFERENCES}

Abalı, Y., \& Kaan, M. (2018). An Analysis of Graduate Theses on Early Childhood Education: The Case of Turkey. The Elementary School Journal, 10(5), 583590.

https://doi.org/10.26822/iejee.2018541 307

Aini, N., Tukiran, \& Qosyim, A. (2013). Model Penemuan Terbimbing (Guided Discovery) pada Pembelajaran IPA Terpadu Tipe Webbed dengan Tema Biopestisida. Jurnal Pendidikan Sains EPensa, 1 (2), 118-122.

Anderson-levitt, K. M., Sirota, R., \& Mazurier, M. (2016). Elementary Education in France. The Elementary School Journal, 92(1).

Antara, A. (2017). Kemampuan Matematika Indonesia Memperhatinkan. Okenews, 1.

Artapati, L. W., \& Budiningsih, C. A. (2017). Pelaksanaan Pembelajaran Kurikulum 2013 di SD Negeri Yogyakarta. Inovasi Teknologi Pendidikan, 4(2), 185-201.

Astra, \& Sumiati. (2008). Metode Pembelajaran. Bandung: Wacana Prima.

Barney, D., \& Deutsch, J. (2012). Attitudes and Perceptions of Elementary Classroom Teachers Use of Physical
Education Time for Planning. The Elementary School Journal, 4(2), 367376.

Cahyani, H., \& Setyawati, R. W. (2016). Pentingnya Peningkatan Kemampuan Pemecahan Masalah melalui PBL untuk Mempersiapkan Generasi Unggul Menghadapi MEA. In Seminar Nasional Matematika $X$ Universitas Negeri Semarang (pp. 151-160).

Condon, M., \& Wichowsky, A. (2018). Developing citizen-scientists. The Elementary School Journal, $119(2)$.

Elfiadi. (2015). Pengaruh Regulasi Diri dan Sikap Pada Matematika Terhadap Kemampuan Memecahkan Masalah Matematika. JUPENDAS, 2(2), 22-30.

Griffen, W. L. (2015). Education's 21st Century Challenge: Breaking the Present Culture Mold. Journal of Thought, 36 (4), 45-52.

Gürbüztürk, O. (2018). Investigation of Elementary Education Students, Attitudes towards the Use of Smart Boards. Journal of Elementary Educatioan, $\quad 11(1)$, 55-61. https://doi.org/10.26822/iejee.2018143 961

Harahap, E. R., \& Surya, E. (2017). Kemampuan Pemecahan Masalah Matematika Siswa Kelas ॥ Dalam Menyelesaikan Permasalahan Linear Satu Variabel. Edumatica, 7(April), 4454.

Kara, F., \& Incikabi, L. (2018). Sixth Grade Students, Skills of Using Multiple Representations in Addition and Subtraction Operations in Fractions *. Journal of Elementary Educatioan, 10(4), $\quad$ 463-474. https://doi.org/10.26822/iejee.2018438 137

Käsper, M., Uibu, K., \& Mikk, J. (2018). Language Teaching Strategies Impact on Third-Grade Students Reading Outcomes and Reading Interest. The Elementary School Journal, 10(5), 601-610. https://doi.org/10.26822/iejee.2018541 309

Kemendikbud. (2016). Kurikulum 2013.

Kemenku. (2017). Membangun Generasi Berkualitas. Media Keuangan, XII(119).

Kim, S., \& Lee, K. (2018). Development and Validation of Self-directed Learning Ability Test ( SDLAT ) for Elementary 
Akhmad Badrul Lubis, Yelvema Miaz, \& Indah Eka Putri, Influence of the Guided Discovery Learning...

School Students. Journal of Elementary

Educatioan, 10(5), 551-557. https://doi.org/10.26822/iejee.2018541 304

Kirksey, J. J., \& Gottfried, M. A. (2018). Familiar faces. The Elementary School Journal, $119(2)$

Kostelecká, Y. (2010). Home education in the post-communist countries: Case study of the Czech Republic. The Elementary School Journal, 3(1).

Lendi, T. N. (2015). Pengaruh Strategi Guided Discovery Learning Terhadap Kemampuan Berpikir Kritis pada Pembelajaran IPA Siswa Kelas V Sekolah Dasar. Jurnal Pendidikan Dasar, 6(2), 266-274.

Mccloskey, M. Lou, \& Quay, L. C. (2018). Effects of Coaching on Handicapped Children 's Social Behavior and Teachers ' Attitudes in Mainstreamed Classrooms. The Elementary School Journal, 87(4).

Nahdi, D. S. (2018). Eksperimentasi Model Problem Based Learning Terhadap Pemecahan Masalah Matematis Ditinjau dari Self Efficay Siswa. Jurnal Cakrawala Pendas, 4(1), 50-56.

Nerita, S., Hartati, Y. S., Maizeli, A., \& Afza, A. (2019). Need Analysis of Disseminate Phase: Handout of Evaluation and Learning Biology Based on Guided Discovery Method. Journal Science Publishing Group, 7(2), 54-57. https://doi.org/10.11648/j.sjedu.201907 02.11

Nupita, E. (2013). Penerapan Model Pembelajaran Penemuan Terbimbing untuk Meningkatkan Hasil dan Keterampilan Pemecahan Masalah IPA pada Siswa Kelas V Sekolah Dasar. JPGSD, 1 (2), 1-9.

Nurhanifah, N. (2018). Perbandingan Peningkatan Kemampuan Pemecahan Masalah Matematis Siswa SMP Antara yang Memperoleh Pembelajaran Means-Ends Analysis ( Mea ) dan Discovery Learning Nova Nurhanifah. In Seminar Nasional Matematika dan Pendidikan Matematika II (pp. 153-161).

Ozerk, K. (2018). Editorial. The Elementary School Journal.

Özsoy, G. (2018). Pre-service Teachers' Use of Visual Representations. Journal of Elementary Educatioan, 11(1), 49-54. https://doi.org/10.26822/iejee.2018143 960

Park, Y. (2017). Examining South Korea's Elementary Physical Education Performance Assessment Using Assessment Literacy Perspectives. The Elementary School Journal, 10(2). https://doi.org/10.26822/iejee.2017236 116

Pasaribu, E. Z. (2017). Perbedaan Peningkatan Kemampuan Pemahaman dan Komunikasi Matematis Siswa Melalui Model Pembelajaran Penemuan Terbimbing. MAJU, 4 (2), 70-81.

Prastiwi, M. D. (2018). Kemampuan Pemecahan Masalah Pada Siswa Kelas VII SMP. E-Jurnal-Pensa, 6(2), 98103.

Prayitno, E. (2015). Konsistensi dan Komitmen Guru Dalam Mencetak Generasi Emas. Jurnal Saung, VII(3), 235-242.

Prearse, R. (2014). The Prediction Private Demand For Education: An Indonesia Case Study. JSTOR, 23(3), 265-285.

Rahayu, D. V., \& Afriansyah, E. A. (2015). Meningkatkan Kemampuan Pemecahan Masalah Matematika siswa Melalui Model Pembelajaran Pelangi Matematika. Jurnal Pendidikan Matematika, 5(April), 29-37.

Redhana, I. W. (2019). Mengembangkan Keterampilan Abad $\mathrm{Ke}-21$ dalam Pembelajaran Kimia. Jurnal Inovasi Pendidikan Kimia, 13(1), 2241.

Rusmiati. (2014). Meningkatkan Hasil Belajar Siswa Kelas IV SDN 1 Inti Pembina Ampibabo Materi Menghitung Keliling Segitiga Melalui Model Pembelajaran Penemuan Terbimbing. Jurnal Kreatif Tadulako, 2(4), 352-371.

Şahin, M. G. (2018). How Classroom Assessment Affects Science and Mathematics Achievement?: Findings from TIMSS 2015. The Elementary School Journal, 10(5), 559-569. https://doi.org/10.26822/iejee.2018541 305

Shabir, M. U. (2015). Kedudukan Guru Sebagai Pendidik. AULADUNA, 2(2), 221-232.

Suryabrata, S. (2006). Metodologi Penelitian.

Temur, T. (2012). Examining Media Literacy Levels of. The Elementary School 
Journal, 4 (2), 269-285.

Ufie, A. (2017). Implementasi Teori Genetik Epistemology Dalam Pembelajaran Guna Memantapkan Perkembangan Kognitif Anak Usia Sekolah. Jurnal Pedagogika Dan Dinamika Pendidikan, 6(1), 25-43.

Ulu, M., \& Özdemir, K. (2018). Determining the Mental Estimation Strategies Used by Fourth-Grade Elementary Students in Four Basic Mathematical Operations. Journal of Elementary Educatioan, 1111), 63-75. https://doi.org/10.26822/iejee.2018143 962

Utami, B., Yamtinah, S., \& Es, W. A. (2016). Analisis Rencana Pelaksanaan Pembelajaran Tematik Yang Digunakan Guru SD. In Seminar Nasional Pendidikan Sains (pp. 361-
366).

Uusiautti, S., Paksuniemi, M., \& Matta, K. (2013). At the Roots of Finnish Elementary Education - How Were Children Raised in the First Finnish Elementary Schools? Journal of Elementary Educatioan, 5(2), 171-184.

Wasserberg, M. J. (2018). "we ' re just scanning through to find the answers." The Elementary School Journal, 119(2), 179-195.

Wijaya, E. Y., Sudjimat, D. A., \& Nyoto, A. (2016). Transformasi pendidikan abad 21 sebagai tuntutan pengembangan sumber daya manusia di era global. In Seminar Nasional Pendidikan Matematika (Vol. 1, pp. 263-278).

Winne, P. H. (1985). Steps toward Achievements. The Elementary School Journal, 85(5), 674-693. 